\title{
CHARACTERISTICS OF THE SHARIA SUPERVISORY BOARD AND ITS RELEVANCE TO ISLAMIC SOCIAL REPORTING AT ISLAMIC BANKS IN INDONESIA
}

\author{
Inten Meutia \\ inten.26@gmail.com \\ Desi Aryani \\ Sari Mustika Widyastuti \\ Faculty of Economics, Sriwijaya University
}

\begin{abstract}
ABSTRAK
Penelitian ini dilakukan untuk menguji pengaruh ukuran Dewan pengawas Syariah (DPS), jumlah rapat DPS, pendidikan DPS, dan rangkap jabatan DPS terhadap Islamic Social Reporting (ISR) menggunakan variabel kontrol ukuran perusahaan serta profitabilitas. Objek penelitian terdiri dari 13 Bank Umum Syariah dan 21 Unit Usaha Syariah yang terdata di Otoritas Jasa Keuangan pada periode 2015-2017. Content Analysis digunakan untuk mengidentifikasi tema dan item pada laporan tahunan bank. Analisis regresi linier berganda merupakan metode yang digunakan dalam pengolahan data. Penelitian ini membuktikan variabel jumlah rapat DPS, rangkap jabatan DPS, ukuran DPS serta profitabilitas berpengaruh signifikan terhadap Islamic Social Reporting. Sementara itu, variabel jumlah DPS dan latar belakang pendidikan DPS ditemukan tidak berpengaruh signifikan terhadap ISR. Hal ini menunjukkan jumlah anggota DPS tidak memberikan kontribusi terhadap pelaporan sosial jika jarang melakukan rapat. Adanya Sertifikasi Dewan Syariah Nasional menyiratkan tidak ada kekhususan latar belakang pendidikan DPS. Penentukan Indeks ISR sangat subjektif, maka diharapkan Dewan Syariah Nasional dapat merancang pedoman khusus penerapan Indeks ISR dan dikonvergensi dengan Indeks ISR lainnnya.
\end{abstract}

Kata kunci: dewan pengawas syariah; bank syariah; islamic social reporting.

\begin{abstract}
This study was conducted to examine the effect of the size of the Sharia Supervisory Board (SSB), the number of SSB meetings, SSB education, and duality in SSB positions on Islamic Social Reporting (ISR) using the control variable of company size and profitability. The object of the study consisted of 13 Sharia Commercial Banks and 21 Sharia Business Units recorded in the Financial Services Authority in the 2015-2017 period. Content Analysis is used to identify themes and items in the bank's annual report. Multiple linear regression analysis is a method used in data processing. This study proves the variable number of SSB meetings, duality in SSB positions, SSB size and profitability significantly influence ISR. Meanwhile, the variable number of SSB and SSB education was found to have no significant effect on ISR. This shows the number of SSB members did not contribute to social reporting if they rarely met. The existence of the National Sharia Board Certification implies that there is no specific SSB educational background. Determination of the ISR Index is very subjective, it is hoped that the National Sharia Board can design specific guidelines for the implementation of the ISR Index and converge with other ISR Indexes.
\end{abstract}

Key words: sharia supervisory board; islamic bank; islamic social reporting

\section{INTRODUCTION}

The definition of Law Number 10 of 1998 explains that banks as financial institutions are tasked with collecting and distributing funds to the public. Bank Indonesia, as the implementing monetary policy, has the authority to issue licenses and revoke business licenses of a bank. Banks in 
Indonesia based on their operational functions are divided into 3 (three), namely central banks, commercial banks, and people's credit banks (Roring, 2013); (Hakiim and Rafsanjani, 2016). Meanwhile, Islamic banking is a banking system whose implementation is guided by Islamic principles or Islamic law (Ilhami, 2009); (Qolby, 2013).

To carry out its business activities, companies that implement Sharia principles have broad potential to attract Muslim investors, as well as other parties who are interested in investing and being involved in the company's business activities (Othman \& Thani, 2010); (Ramadhani 2016); (Nuralam, 2017). Therefore, the report presented by the company must be based on Sharia principles and carry out corporate social responsibility disclosure Corporate Social Responsibility (CSR) according to Ramadhani (2016). CSR is an active role of companies in contributing to the achievement of public welfare (Friedman, 2007); (Murphy \& Ng'ombe, 2009); (Garriga \& Melé, 2013); (Masrurroh \& Mulazid, 2017).

Disclosure of social responsibility in Islamic financial institutions better known as Islamic Social Reporting (ISR) is now a necessity and an interesting topic of conversation (Fitria \& Hartanti, 2010) ISR is the development of social reporting not only involving the holistic expectations of society about the role of companies in the community but also viewed from a spiritual perspective (Othman \& Thani, 2010); (Hafiez et al., 2012); (Zanariyatim et al., 2016); (Meutia \& Febrianti, 2017). ISR becomes very important because it can show the accountability of the company to stakeholders (Maali et al., 2006); (Othman \& Thani, 2010); (Lestari, 2013). The ISR index was expanded again by researchers consisting of ISR indicator items that must be disclosed by Islamic financial institutions (Hafiez et al., (2012). The ISR index has 6 (six) themes covering finance and investment, products and services, employees, social, environment and corporate governance, in total 49 indicators (Othman et al., 2009); (Othman \& Thani, 2010); (El-
Halaby \& Hussainey, (2015). According to Charles dan Chariri (2012), the party holding the role in the implementation and disclosure of the ISR is the SSB. SSB occupies a strategic position in the hierarchy of Islamic financial institutions (Nathan Garas \& Pierce, 2010). SSB has the same authority and position in Islamic financial institutions as the board of commissioners (Farook et al., 2011). The existence of SSB is very important in the supervision process because SSB has the authority to advise on Shariah compliance to management in Sharia financial institutions (Al-Sadah, 2007); (Nathan Garas \& Pierce, 2010); (Farook et al., 2011); (Nathan Garas, 2012). The Accounting and Auditing Organization for Islamic Financial Institutions (AAOIFI) established Governance Standard no. 1 in the Governance Standards for Islamic Financial Institutions (GSIFI) governing the existence of SSB in Sharia financial insti- tutions (Charles dan Chariri, 2012); (Sulai- man et al. 2015); (El-Halaby \& Hussainey, 2016). In Indonesia, SSB is legally protected by Law Number 40 of 2007 concerning Limited Liability Companies in article 109 discussing the SSB position. Then Act Number 21 of 2008 concerning Sharia banking, article 23 regulates the position of SSB in Sharia banking. Another thing that becomes a reference in SSB supervision is Bank Indonesia Regulation Number 11/33/ PBI/2009 which regulates the implementation of good governance for Sharia Commercial Banks and Sharia business units.

SSB is an independent Sharia body and economist that has the role of directing, controlling, reviewing and ensuring compliance with Sharia principles in Islamic financial institutions (Al-Sadah, 2007); (Nathan Garas \& Pierce, 2010); (Garas, 2012); (Rokan, 2017); (Sulistyawati \& Yuliani, 2017). According to Nuha, (2018) SSB as the body in charge of overseeing the implementation of fatwas and decisions determined by the National Sharia Council. Some of these opinions were confirmed by Hashim et al., (2015); Mukhibad (2018) who stated the existence of SSB is an internal advisor in 
Islamic financial institutions, has a holistic function of Shariah compliance related to economic and social performance. Furthermore, Rahajeng (2013) explains that SSB also acts as an independent body of legal specialists in fiqh al muamalat (Islamic commercial jurisprudence). Considering the role of SSB is very important in Islamic financial institutions and the effect of SSB on ISR, this study will examine in more detail the characteristics of SSB and its relevance to ISR.

Previously some studies tried to identify factors that influenced ISR including, Billzha (2018); Prastiwi (2017); Rahayu dan Cahyati (2014); Rosiana et al., (2015); Ramadhani, (2016); Maghfur (2018). Billzha (2018) examines SSB characteristic variables including SSB educational background, SSB expertise, SSB size, duality in SSB positions and SSB reputation. Prastiwi (2017) identified SSB characteristic variables namely SSB size, SSB meeting frequency, and SSB education background. Rahayu dan Cahyati (2014) tested SSB size variables, SSB meeting frequency, profitability, company size, leverage and the size of the board of commissioners on ISR. Rahayu dan Cahyati (2014) tested SSB size variables, SSB meeting frequency, profitability, company size, leverage and the size of the board of commissioners on ISR. Rosiana et al., (2015) identified SSB characteristic variables including size, profitability and leverage, Islamic governance, SSB reputation, and SSB education background on ISR. Ramadhani (2016) tested the SSB size, size, and profitability variable for ISR. Furthermore, Maghfur (2018) also examines SSB characteristic variables including firm size, firm age, SSB meeting frequency, SSB size and profitability to ISR.

From previous studies, it is known that there have been many studies using SSB size variables, several SSB meeting frequencies and SSB education background on ISR in Islamic financial institutions. The results of the reviews obtained from previous studies vary greatly. Therefore, in this study, the researcher will include these three variables.
This study also added the dual position variable as a new variable that had not previously been studied. This is based on Bank Indonesia regulation No. 11/3/2009 article 36 paragraph stating that SSB members can perform duality in their positions as SSB members in 4 (four) different Sharia financial institutions. Because it is suspected that if SSB implements duality in positions in more than 4 (four) Islamic financial institutions, it will interfere with SSB performance.

Based on the description stated above, this study was conducted to provide a complete picture of the role of SSB through SSB characteristics consisting of SSB size, number of SSB meetings, SSB education background, and duality in SSB positions on ISR disclosure using ISR control variables company and profitability.

\section{STUDY LITERATURE AND HYPO- THESIS DEVELOPMENT \\ Stewardship Theory}

Stewardship Theory is a depiction of the condition of managers who are motivated from the main results of the interests of the organization rather than motivated against his interests (Donaldson \& Davis, 1991); (Davis et al., 1997); (Muth \& Donaldson, 1998); ((Albrecht et al., 2004); Keay, 2017). The individual holds the agreement about the organization as a binding moral commitment between the two parties (Caldwell, Bischoff, \& Karri, 2002) ; (Caldwell, Hayes, Bernal, \& Karri, 2008). This theory has basic psychology and sociology that are arranged so that executives who act as stewards (management) are encouraged to do as the principal wishes (Muth \& Donaldson, 1998); (Albrecht et al., 2004); (Bindabel, 2017). Steward behavior does not neglect the organization where it works because it wants to achieve the goals of the organization (Husain dan Abdullah, 2015); (Marharani \& Yulianto, 2016). In company management, Stewardship theory has a role to maintain harmony and trust given by the principal to stewards (Zoelisty and Adityawarman, 
2014). Stewardship Theory suggests that managers include individuals who consider fairness and care for the interests of others (Buchanan, 1996) and consider themselves to be professional, company stewards. Company goals take precedence over personal interests (Hernandez, 2012). As professionals, they will make personal sacrifices, act honestly and diligently (Blair \& Stout, 2001). Arrangements by company management must be accountable for the sake of the public good.

In some studies, the characteristics of SSB on the disclosure of ISR are many who use theories such as Stakeholders' theory, Legitimacy and Sharia Enterprise Theory. In this study, researchers tried to use the Stewardship theory. Stewardship Theory is a description of Steward who acts by the wishes of the principal. Stewardship Theory is intended to examine situations where executives in a company as stewards can behave best on the principal (Marharani \& Yulianto, 2016).

Previously it was known that SSB is a supervisor in ensuring sharia compliance that has the same goals as an Islamic bank. Stewardship is a description of managers who act in the best way according to the wishes of the principal. This is almost the same as the function of SSB as a supervisor in ensuring sharia compliance with ISR disclosure. In the Stewardship perspective management should act as such. Management acts as a Steward in which management behavior must be the same as the goals of the organization. Therefore, in this study researchers used the Stewardship theory to link the role of SSB and stewards in ensuring sharia compliance in Islamic banks in Indonesia.

\section{Islamic Social Reporting (ISR)}

Islamic Social Reporting is the development of a conventional reporting system that not only contains material, social and moral aspects, but also contains matters relating to Sharia principles, including Sharia compliance, paying zakat, activities that are free from the application of interest/usury, gharar and aspects social aspects, such as saddaqah, waqf, qardhul hassan (Lestari, 2013); (Indrawaty \& Wardayati, 2016). Islam wants harmony between economic and spiritual activities in conducting business activities. In Islamic Sharia there are three interrelated dimensions, namely seeking God's pleasure as the main goal in building socio-economic justice, providing benefits to society, and creating prosperity (Haniffa, 2002); Maghfur (2018).

Islamic perspective is an understanding related to corporate accountability that is shown to the public to increase transparency, social justice and corporate social ownership (Haniffa, 2002); (Maali et al., 2006); (Lestari, 2013). Large-scale financial institutions tend to face higher demand for information related to company conditions compared to small-scale financial institutions (Ramadhani, 2016). Furthermore, Haniffa (2002) developed 5 (five) themes in the disclosure of ISR and Othman et al., (2009) added 1 (one) theme, namely:

1. Finance and Investment

The basic concepts in this theme are monotheism, halal, haram, and compulsory. Related items are sources of funds for investment and financing activities that do not have the element of usury, zakat, gharar, transactions that are not recommended in Islam, investment activities, and related financing projects.

2. Products and Services

Some aspects that need to be revealed on this theme are the halal status of the products used and the service of consumer complaints.

3. Employees

In ISR everything related to employees comes from the concepts of ethics, trust and justice, namely the number of hours worked by employees, holidays, employee benefits and remuneration, employee education and training, employee involvement, employee safety, work environment, employees from special 
groups and place of worship for employees

4. Social

The concepts that underlie this theme are the ummah, amanah, and 'adl. The concept emphasizes the importance of mutual diversity and lightens the burden on society. Islam emphasizes its people to share. The focus on Islamic principles includes items saddaqah, waqf, qard hassan, along with other charitable activities.

5. Environment

The concepts that underlie this theme are mizan, iididal, khilafah, and akhirah. The concept emphasizes the principle of balance, simplicity, and responsibility in protecting the environment.

6. Corporate Governance

The concept that underlies this theme is the khilafah.

\section{Size of the Sharia Supervisory Board}

The size of SSB is the number of SSB members in an Islamic financial institution (Khoiruddin, 2013). According to PBI (2009), SSB membership is a minimum of 2 (two) people. The number of SSB members in Islamic financial institutions will lead to better Shariah compliance (Nathan Garas, 2012). This is because, the existence of SSB's collective knowledge and experience is expected to lead to wider ISR disclosure (Farook et al., 2011); (Rahayu \& Cahyati, 2014); (El-Halaby \& Hussainey, 2016). Also, a higher number of SSB members can reduce uncertainty and lack of information (Birnbaum, 1984). SSB in carrying out the supervision of Islamic financial institutions by the fatwa given by the National Sharia Council (DSN) according to Rama, (2015). DSN cooperates with Bank Indonesia and the Financial Services Authority in the process of appoint- ing SSB membership.

\section{Number of Sharia Supervisory Board Meetings}

The presence of directors and committees at the board of directors meetings are urgently needed by directors and share holders (Widayuni and Hartono, 2014); (Gray \& Nowland, 2013). SSB members in Islamic financial institutions have a minimum of 1 (one) meeting in 1 (one) month (PBI, 2009). The existence of SSB is almost the same as the audit committee's aim to oversee Islamic financial institutions. The high frequency of meetings conducted by SSB will affect better CSR disclosure (Charles and Chariri, 2012); (Rahayu and Cahyati, 2014). This is due to the coordination and supervision process carried out by SSB in Islamic financial institutions (Al-Tuwaijri et al., 2004).

\section{Educational Background of the Sharia Supervisory Board}

The competency that must be possessed by SSB is not only expertise in terms of Islamic law. SSB members must have insight and experience in the field of Sharia banking, general finance, and competence in the field of Sharia muamalah (Ramadhani, 2016); (Mukhibad 2018). This statement is confirmed by Farook et al., (2011); Mukhibad (2018) that in addition to understanding religious issues, SSB must understand legal, economic and financial issues. Because the diversity of education owned by SSB will affect the quality of social reporting on Islamic banks.

Halal and illicit banking activities and products will be difficult to determine if SSB only understands Islamic law, without having expertise in other aspects such as the manufacture of products, or the legality of a Sharia product in Islamic law (Charles and Chariri, 2012). In practice, Islamic banking follows conventional accounting practices. However, Islamic banking also implements practices based on the DSN fatwa whose implementation is overseen by DSN (Nuha, 2018).

\section{Dual Position of Sharia Supervisory Board}

Dual positions are considered as an issue that influences SSB performance. Estimated to influence the level of focus and effectiveness of SSB in carrying out their 
duties. Dual positions can create a conflict of interest (Gary \& Nowland, 2012). Therefore, these conditions need to be considered because they can cause a conflict of activities (Rahayu \& Cahyati, 2014). SSB members may not be able to attend meetings scheduled at one bank because of interests at another bank.

According to PBI No. 11/3/2009, SSBs are allowed to perform duality in their positions as members of SSBs only in a maximum of 4 (four) Islamic financial institutions. That is because, if SSB occupies dual positions in more than 4 (four) Islamic financial institutions, it can interfere with SSB performance.

\section{Prior Research}

Previous studies related to ISR that have been successfully excavated include: Research by Charles and Chariri (2012) of 8 (eight) independent variables, 7 (seven) variables affect CSR disclosure. But 4 (four) variables include the board of commissioners' meeting, the composition of the independent commissioners, the size of the board of commissioners, the composition of the independence of the audit committee found to have a negative coefficient. While the variable size of the board of commissioners, Islamic Governance (IG), size of the board of commissioners, audit committee meetings was found to have a positive effect on CSR disclosure. Charles dan Chariri (2012) use the population of Islamic banks in Asia. The sample consists of 7 (seven) Sharia banks as members of AAOIFI and 3 (three) Sharia banks in Indonesia who are non-members, but the banks have adopted regulations and standards regulated by AAOIFI.

Lestari (2013) revealed that there was a significant influence between profitability and company size variables on ISR disclosure. However, firm age variables and the proportion of the board of commissioners did not significantly influence the disclosure of ISR. The study was conducted at 18 Sharia Commercial Banks in Indonesia for the period 2010-2011. Rahayu dan Cahyati (2014) found that all Sharia banks had disclosed CSR. But the variable number of SSB meetings, SSB size, leverage, and company size do not affect the extent of CSR disclosure. While the profitability variable has a negative effect and the board of commissioners has a positive effect on CSR disclosure. The study population is Sharia banking in Indonesia in the period 2011-2014.

Furthermore, the research of Rosiana et al., (2015) explains that company size variables have a significant influence on ISR disclosure. However, the leverage, profitability and Islamic Governance Score (IGS) variables whose measurement through a large number of cross membership, SSB reputation, and educational background do not affect ISR disclosure. The growth of IGS in Islamic banking in Indonesia is still new. IGS which has been good in Islamic banking cannot guarantee whether it will provide better ISR disclosure or vice versa. The study population was 10 Sharia Commercial Banks in Indonesia for the period 2010-2012.

Ramadhani, (2016) found that the SSB size variable, size companies and leverage influence the disclosure of ISR. However, profitability variables do not affect on ISR disclosure. The population of the study is Sharia Commercial Banks in Indonesia for the period 2010-2014. Further research conducted by Sulistyawati \& Yuliani (2017) found that independent commissioner variables had a positive and significant effect on ISR disclosure. However, firm size, profitability and leverage variables do not affect ISR disclosure.

The research sample is companies listed on the Indonesian Sharia Stock Index (ISSI) of the Indonesia Stock Exchange totaling 39 companies in the 2012-2014 period.

Maghfur (2018) revealed that company size and frequency of SSB meeting variables had a positive and significant effect on ISR disclosure. Furthermore firm age, profitability, and SSB size variables do not affect ISR disclosure. The research sample of 8 (eight). Sharia Commercial Banks for the period 2012-2016. 


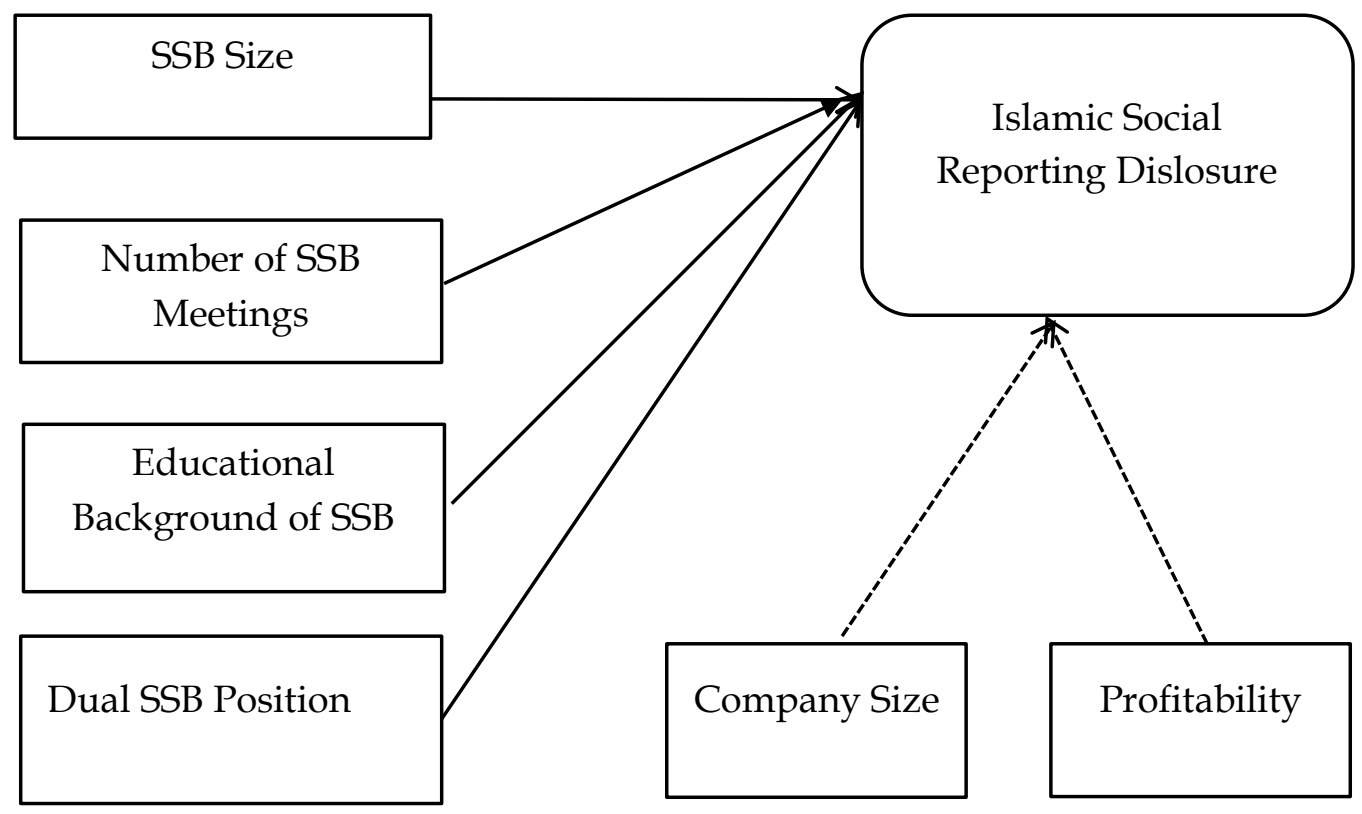

Figure 1

Framework

Based on the description above, it is concluded that the SSB size variable obtained 2 (two) differences in the results of the study. Charles dan Chariri (2012); Ramadhani (2016); Sulistyawati \& Yuliani (2017) stated that the SSB size variable showed an influence on ISR. Lestari (2013); Rosiana et al., (2015); Maghfur (2018); Rahayu dan Cahyati (2014) stated that the SSB size variable did not affect on the ISR. While the second variable is the number of SSB meetings. Research conducted by Maghfur (2018) explains that the frequency of SSB meetings has a significant effect. Rahayu dan Cahyati (2014) found that the SSB meeting frequency variable had no significant effect. Furthermore, Rosiana et al., (2015) revealed that educational background variables did not significantly influence ISR.

Various studies have been explored by researchers, but no one has raised the issue of dual position as part of the characteristics of SSB. Therefore this study was carried out to identify the characteristics of SSB and how they affect the size of SSB, frequency of SSB meetings, SSB education background and dual positions in SSB positions on ISR disclosure using control variables of company size and profitability.

As explained earlier, the framework for this study can be seen in Figure 1. The hypothesis formulation based on the above mindset is:

The SSB size, number of SSB meetings, SSB education background, and duality in SSB positions affect ISR.

\section{METHODOLOGY}

This research is quantitative. The object of research used is Sharia Commercial Banks and Sharia Business Units in Indonesia in 2017 Financial Services Authority data. The type of data in this study is secondary data sourced from annual reports. Data obtained through the website of the Sharia Commercial Bank and Sharia Business Unit. Registered Syariah Commercial Banks are 13 banks and Syariah Business Units are 21 banks.

Content analysis is used to identify the contents of the ISR in the bank's annual report. Content analysis is a method that has been widely applied in research that 
identifies the content or content of an annual report (Campopiano \& De Massis, 2015); (Gao, 2011); (Bouten, Everaert, Van Liedekerke, De Moor, \& Christiaens, 2011); (Abul Hassan, 2010).

\section{Variable Measurement}

ISR measurement using (Othman et al., 2009) is a reference in measuring ISR. There are 49 items in 6 (six) themes covering, finance and investment, products or services, employees, social, environment, and corporate governance.

The indexing measurement is done by giving a score of " 0 " if the item is not disclosed, while a score of " 1 " is given if the item is disclosed (Hafiez et al., 2012). The index value is obtained by dividing the total items disclosed by the entity by the total items that must be disclosed.

$$
\text { ISRD }=\frac{\text { Total items disclosed }}{\text { Total items must be disclosed }} \times 100
$$

The SSB measure is the number of SSB members in sharia institutions.

$$
\text { USSB }=\sum \text { Number of SSS Members }
$$

The number of SSB meetings is the number of frequency of meetings held by SSB in one year.

$$
\text { RSSB }=\sum \text { Number of SSB Meetings }
$$

The educational background in this study is the diversity of SSB education covering religion, economics, and law. This measurement refers to research conducted by Othman et al., (2009). A score of "1" is given to banks that have a variety of SSB educational backgrounds. A score of "0" is given to banks that do not have SSB with these 3 criteria.

Duality in position is a condition of SSB members in holding 2 or more positions. Dual SSB member positions can only be made to a maximum of 4 (four) Sharia entities. The measurement method used is the dummy method using a nominal scale. A score of "1" is given to the bank if one SSB member is occupying more than 4 Islamic financial institutions. A score of " 0 " is given to banks with SSB occupying positions of less or equal to 4 in Islamic financial institutions.

The control variables in this study are size and profitability. The control variable is used because many previous studies have proven that there is an influence between company size and profitability on social reporting (Widayuni \& Hartono, 2014); (Rahayu \& Cahyati, 2014); (Abul Hassan, 2010); (McWilliams \& Siegel, 2000); (Sadou, Alom, \& Laluddin, 2017); (El-Halaby \& Hussainey, 2015); (Mallin, Farag, \& OwYong, 2014). Size is proxied by Ln (total assets) at a Sharia Commercial Bank and Sharia Business Unit. The measurement of profitability by using the ratio of Return on Assets (ROA).

$$
R O A=\frac{\text { Net Profit }}{\text { Total Assets }} \times 100 \%
$$

The analysis applied in this research is multiple regression. Multiple regression analysis to develop the research model (Tiaraintan Hariyanto \& Suhardianto, 2018); (Putra et al., 2018); (Humaidi et al., 2018) and test whether the four selected factor variables can influence the ISR index. The relationship between the four factors with ISR is illustrated by the following equation:

$$
\begin{array}{lll} 
& \text { ISR }=\alpha+\beta_{1} \text { USSB }+\beta_{2} \text { RSSB }+\beta_{3} \text { PSSB }+\beta_{4} \text { RJBT }+\beta_{5} \text { SIZE }+\beta_{6} \text { PROFIT }+ \\
\text { USSB } & =\text { SSB size } & \text { SIZE }=\text { Company Size } \\
\text { RSSB } & =\text { Number of SSB Meetings } & \text { PROFIT }=\text { Profitability } \\
\text { PSSB } & =\text { Educational Background of SSB } & \text { ISR }=\text { Islamic Social Reporting } \\
\text { RJBT } & =\text { Duality in SSB Position } & \beta_{0}=\text { Coefficient of Multiple Regression }
\end{array}
$$




$$
\mathrm{a} \quad=\mathrm{A} \text { constant }
$$$$
\varepsilon=\text { Error Term }
$$

RESULTS AND DISCUSSION
Table 1 and Table 2 are data that show the value of each research variable in the sample banks, namely Sharia Commercial Banks and Sharia Business Units.

Table 1

Descriptive Research Variables at Islamic Commercial Banks

\begin{tabular}{clccccc}
\hline No & \multicolumn{1}{c}{$\begin{array}{c}\text { Name of Sharia } \\
\text { Commercial Bank }\end{array}$} & ISR & SSSB & RSSB & PSSB & RJBT \\
\hline 1 & Bank Aceh Syariah & 0,67 & 2 & 10 & 1 & 0 \\
2 & Bank Muamalat Indonesia & 0,78 & 3 & 12 & 0 & 0 \\
3 & Bank Victoria Syariah & 0,53 & 2 & 23 & 0 & 0 \\
4 & Bank BRI Syariah & 0,73 & 2 & 12 & 0 & 0 \\
5 & Bank Jabar Banten Syariah & 0,63 & 3 & 12 & 1 & 0 \\
6 & Bank BNI Syariah & 0,69 & 2 & 19 & 0 & 1 \\
7 & Bank Syariah Mandiri & 0,71 & 3 & 9 & 1 & 1 \\
8 & Bank Mega Syariah & 0,71 & 2 & 13 & 0 & 1 \\
9 & Bank Panin Dubai Syariah & 0,69 & 2 & 27 & 1 & 1 \\
10 & Bank Syariah Bukopin & 0,69 & 2 & 14 & 0 & 1 \\
11 & BCA Syariah & 0,71 & 2 & 14 & 1 & 1 \\
12 & Maybank Syariah Indonesia & 0,61 & 2 & 12 & 0 & 0 \\
13 & Bank Tabungan Pensiunan & 0,61 & 2 & 12 & 0 & 1 \\
\hline
\end{tabular}

The data in Table 1 above shows that Bank Muamalat Indonesia has the highest ISR index (0.78) compared to other banks. While the lowest ISR index (0.53) is found in Victoria Syariah Bank. The high ISR index of Bank Muamalat is possible because Bank Muamalat is the first Sharia bank established in Indonesia, so it has more experience in managing social reporting. The size or number of SSB in each Sharia bank ranges from 2 to 3 people. This is by PBI Nomor $11 / 3 / P B I / 2009$ which requires that there are at least two SSB members in one Sharia bank. Banks that have 3 (three) SSB are Muamalat Bank, Banten Jabar Banten Syariah Bank, and Mandiri Syariah Bank.

About the number of SSB meetings in one year, Panin Dubai Syariah Bank has the highest number of meetings, 27 times. While the least conducted meetings were Bank Syariah Mandiri, only 9 times. The obligation of SSB to conduct meetings according to PBI Number 11/33 /PBI / 2009 is at least once a month, meaning twelve times a year. Bank
Syariah Mandiri was established relatively longer than Bank Panin Syariah and had more SSB members than Bank Panin Dubai Syariah. However, this does not mean that the SSB has more meetings according to Bank Indonesia regulations.

Related to educational background variables, only 5 (five) Sharia commercial banks have SSB with various fields of education (religion, law, and economics). Eight other banks do not have SSB members with diverse educational backgrounds. Whereas diverse educational backgrounds will help SSB to carry out its functions more optimally This is in line with research by Andriana, Muhamad, Meutia, \& Natalia (2015).

Out of the 17 (seventeen) Sharia banks, 7 (seven) banks, SSB members carry out the duality in positions in more than 4 (four) Sharia banks. While SSB in 8 (eight) other Sharia banks have fulfilled Bank Indonesia regulations, do not allow duality in positions in more than 4 (four) banks. 
This dual position regulation is closely related to the implementation of the SSB function. The more SSB of a bank doing dual positions as SSB in other banks, the more likely there are obligations or tasks to be ignored

Furthermore, the data in Table 2 illustrates how the condition of the Sharia Business Unit is based on the five main research variables, namely the social reporting index (ISR), the SSB size (SSSB), the number of SSB meetings in one year (RSSB), the educational background of SSB members (PSSB) and dual position of SSB (RJBT) member. The data in Table 2 shows the highest ISR index (0.80) for the Sharia Business Unit category found in Bank
Permata Syariah. While the lowest ISR index (0.55) was found in Jambi BPD and South Kalimantan BPD. When viewed from the year of its establishment, the Permata Bank Syariah and the Central Kalimantan Syariah Business Unit were established in 2004, while the Syariah Syariah Bank BPD Jambi was established in 2011. In this case, the duration of the bank standing does not seem to be a driver of the ISR index.

Judging from the size of SSB, the largest number of SSB (4) is found in Maybank Indonesia. This differs from data from Sharia Commercial Banks, where the largest number of SSB members is only 3 people. Meanwhile, other Sharia Business Units have SSB members of between 2 to 3 people.

Table 2

Descriptive Research Variables in Sharia Business Units

\begin{tabular}{cllcccc}
\hline \hline No & Name of Sharia Business Unit & ISR & SSSB & RSSB & PSSB & RJBT \\
\hline 1 & Bank Danamon Indonesia, Tbk & 0,73 & 2 & 12 & 0 & 1 \\
2 & Bank Permata, Tbk & $0,80^{*}$ & 2 & 17 & 1 & 0 \\
3 & Bank Maybank Indonesia, Tbk & 0,77 & 4 & 23 & 0 & 0 \\
4 & Bank CIMB Niaga, Tbk & 0,76 & 3 & 24 & 0 & 0 \\
5 & Bank OCBC NISP, Tbk & 0,73 & 2 & 15 & 0 & 0 \\
6 & Bank Sinarmas & 0,73 & 2 & 12 & 0 & 0 \\
7 & Bank Tabungan Negara (Persero), & 0,73 & 3 & 17 & 1 & 0 \\
8 & Tbk & 0,65 & 2 & 16 & 0 & 0 \\
9 & BPD DKI Daerah Istimewa Yogyakarta & 0,63 & 2 & 14 & 0 & 0 \\
10 & BPD Jawa Tengah & 0,76 & 2 & 13 & 1 & 0 \\
11 & BPD Jawa Timur, Tbk & 0,78 & 3 & 9 & 0 & 0 \\
12 & BPD Sumatera Utara & 0,71 & 3 & 10 & 1 & 0 \\
13 & BPD Jambi & $0,55^{*}$ & 2 & 15 & 0 & 0 \\
14 & BPD Sumatera Barat & 0,69 & 3 & 27 & 1 & 0 \\
15 & BPD Riau dan Kepulauan Riau & 0,74 & 2 & 15 & 0 & 0 \\
16 & BPD Sumsel Babel & 0,71 & 3 & 13 & 0 & 0 \\
17 & BPD Kalimantan Selatan & $0,55^{*}$ & 2 & 12 & 0 & 0 \\
18 & BPD Kalimantan Barat & 0,63 & 3 & 23 & 0 & 0 \\
19 & BPD Kalimantan Timur & 0,59 & 2 & $0^{*}$ & 0 & 0 \\
20 & BPD Sulawesi Selatan \& Barat & 0,67 & 2 & 9 & 0 & 0 \\
21 & BPD Nusa Tenggara Barat & 0,74 & 2 & $45^{*}$ & 0 & 0 \\
\hline
\end{tabular}


The highest number of meetings held by SSB per year (45 times) is conducted by the Sharia Business Unit of the West Nusa Tenggara BPD. Whereas the Sharia Commercial Bank of the East Kalimantan BPD has never held a SSB meeting. Other BPD Syariah Banks have met the meeting criteria set by Bank Indonesia, which are at least 12 times a year. However, there are still two Sharia Business Units that do not comply with the provisions, including Sharia Business Units from BPD East Java, North Sumatra, and South \& West Sulawesi.

Furthermore, out of the 21 Sharia Business Units that were sampled in this study, as many as five Sharia Business Units that have SSB members with diverse educational backgrounds (religion, economics, and law), namely Syariah Business Units Bank Permata, BTPN, Central Java BPD, North Sumatra BPD and West Sumatra BPD. In terms of dual positions, there is only one Sharia Business Unit, the Bank Danamon Syariah Business Unit, whose SSB members have multiple positions in more than 4 other Sharia banks. In terms of dual positions, it seems that the Sharia Business Unit of the Regional Bank is far more compliant with Bank Indonesia regulations. Next, Table 3 shows the minimum, maximum and mean values of the research variables, namely the ISR index, the SSB size, the number of SSB meetings, SSB education, dual SSB positions, company size, profitability.

Table 3

Descriptive Statistics of Research Variables

\begin{tabular}{lcrrr}
\hline \hline & N & Minimum & Maximum & Mean \\
\hline ISR & 102 & 0.53 & 0.81 & 0.70 \\
USSB & 102 & 2 & 4 & 2.35 \\
JRPT & 102 & 0 & 45 & 14.14 \\
PSSB & 102 & 0 & 1 & 0.29 \\
RJBT & 102 & 0 & 1 & 0.23 \\
SIZE & 102 & 27.87 & 33.22 & 30.87 \\
ROA & 102 & -0.2 & 0.2 & 0.016 \\
Valid N & 102 & & & \\
(listwise) & & & &
\end{tabular}

Source: data processed

The data in Table 3 shows the lowest ISR index of 0.53 , the highest ISR index of 0.81 with an average index of 0.70 . In general, this shows that the ISR index of both Sharia Commercial Banks and Sharia Business Units is already above 50 percent. The ISR index above 50 percent according to Julia, Rahman, \& Kassim, (2016) has shown there are good intentions from companies to carry out social activities based on Sharia principles.

The SSB size shows that the minimum number of SSB is 2 and the maximum is 4 (four). This shows that the compliance of
Sharia Commercial Banks and Sharia Business Units to meet the minimum requirements for SSB members as stipulated in the PBI is sufficient.

Meanwhile, the number of meetings conducted by SSB during one calendar year ranged from 0 to 45 times. This shows that there are still Sharia Commercial Banks and Sharia Business Units that do not hold meetings as regulated in the PBI.

Test results The coefficient of determination shown in Table 4 shows an R2 of 0.274 . This shows that the SSB size variable, the number of SSB meetings, SSB education 
and dual positions in the SSB position gave variation to the ISR index of $27.40 \%$. While the rest is explained by other variables outside this research variable.

Table 4

Determination Coefficient Test Results

\begin{tabular}{rrrrr}
\hline Model & R & R Square & Adjusted R Square & \multicolumn{2}{c}{$\begin{array}{c}\text { Std. Error of the } \\
\text { Estimate }\end{array}$} \\
\hline 1 & $.563^{a}$ & 0.317 & 0.274 & 0.05542
\end{tabular}

a. Predictors: (Constant), ROA, RJBT, JRPT, PSSB, SIZE, USSB

b. Dependent Variable: ISR

Source: data processed

Table 5

Hypothesis Test Results (T-test Results)

\begin{tabular}{|c|c|c|c|c|c|c|}
\hline & \multirow{2}{*}{ Model } & \multicolumn{2}{|c|}{$\begin{array}{r}\text { Unstandardized } \\
\text { Coefficients }\end{array}$} & \multirow{2}{*}{$\begin{array}{r}\begin{array}{r}\text { Standardized } \\
\text { Coefficients }\end{array} \\
\text { Beta }\end{array}$} & \multirow[t]{2}{*}{$\mathbf{T}$} & \multirow{2}{*}{ Sig. } \\
\hline & & B & $\begin{array}{l}\text { Std. } \\
\text { Error }\end{array}$ & & & \\
\hline \multirow{7}{*}{1} & (Constant) & -0.02 & 0,09514 & & -0.143 & 0,61597 \\
\hline & SSSB & 0.008 & 0.012 & 0.062 & 0,43194 & 0,37222 \\
\hline & RSSB & 0.002 & 0.001 & 0,14792 & 2.413 & $0.018^{*}$ \\
\hline & PSSB & 0.018 & 0.013 & 0,08611 & 1.405 & 0,11319 \\
\hline & RJBT & 0.028 & 0.014 & 0,12778 & 2.057 & $0.042^{*}$ \\
\hline & SIZE & 0.021 & 0.005 & 00.43 & 4.528 & $0.008^{*}$ \\
\hline & ROA & 0.074 & 0,10347 & 0.044 & 0,34514 & $0.015^{*}$ \\
\hline
\end{tabular}

a. Dependent Variable: ISR

Source: data processed

T-test results that show the effect of each independent variable on the ISR index can be seen in the following Table 5 .

The data in Table 5 shows the variable number of SSB meetings, multiple SSB positions, bank size and profitability that have a significant influence (P-value $<0.05$ ). While 2 (two) other variables, SSB size and SSB education did not show a significant effect (P-value> 0.05). Many meetings held by SSB in 1 (one) year affect the ISR index disclosed by the company. This shows that with a large number of meetings, it is likely that SSB has more time to discuss other matters outside the main task. SSB ensures Sharia bank compliance in carrying out its daily operations. Duality in position is another significant factor that also affects the
ISR index of Islamic banks. Being a SSB member at many other Sharia banks will disrupt SSB activities as stated (Rahayu \& Cahyati, 2014). Therefore, the Financial Services Authority Regulation Number 30/ POJK.05/2014 limits dual positions only to a maximum of 4 other banks. Becoming a SSB member in more than 4 Sharia banks will disrupt the time owned by SSB members to supervise Sharia banks properly, including in terms of social reporting.

The two control variables, size, and profitability, as expected, have a significant effect (P-value $<0.05$ ) on the ISR index. Banks that have large assets will certainly try to show more attention to corporate social reporting. This is in line with the findings (Othman \& Thani, 2010); (Kamla \& Rammal, 
2013); (Meutia \& Febrianti, 2017). Likewise, companies that are in good financial condition, will have more resources to show their social responsibility. As found also in research (Giannarakis, 2014); (Gamerschlag, Möller, \& Verbeeten, 2011); (Muttakin, Khan, \& Subramaniam, 2015).

In this study, SSB size and SSB education background are two variables that do not influence the ISR index. This means that a little or a lot of SSB members do not contribute much to social reporting conducted by Islamic banks. A large number of SSB members will not contribute if meetings are rarely held. On the other hand, frequent meetings will allow SSB members to submit their fatwas and views to encourage banks to pay more attention to social issues based on Islamic views. Grassa, (2013) states that SSB is a board that has an important role in ensuring Islamic banks comply with Islamic rules. In this case, fewer SSB members but who are more active in the meeting will provide better benefits to Islamic banks.

The educational background of SSB members is also not a significant variable on the ISR index. This happens because it is possible to become a member of SSB in Indonesia required to follow certification held by the National Sharia Board. SSB members must pass the exam to become an SSB. So SSB members with any educational background can have a good understanding of the principles of Islamic Sharia. Therefore, in this case, the formal education background does not become too significant.

\section{CONCLUSIONS, LIMITATIONS AND SUGGESTIONS \\ Conclusions}

This study was conducted to examine the effect of SSB size, frequency of SSB meetings, SSB education, and dual SSB positions on ISR in Sharia Commercial Banks and Sharia Business Units in Indonesia. The control variables used are company size and profitability. Based on the findings, this study concludes the following: Of the four variables 2 (two) variables have a significant contribution to the ISR. The variable is the number of SSB meetings and dual SSB positions. Because it is proven that more frequent meetings are held, the ISR index is getting better. It turns out that the existence of SSB in more than 1 bank, this can affect the performance of the ISR. But in this study, SSB size variables and SSB education background were found to have no significant contribution.

\section{Suggestions}

As the tests have been carried out, suggestions for future research include:

1. Sharia Commercial Banks and Sharia Business Units can present ISR disclosure more broadly at a better level.

2. The low coefficient of determination in this study is possible because the variables used are still small. Future research is expected to be able to add variables that theoretically influence on ISR.

3. Future research is expected to expand the objects to be examined. Besides Sharia Commercial Banks and Sharia Business Units such as the Jakarta Islamic Index (JII) or the Indonesian Sharia Stock Index (ISSI).

\section{Limitations}

The subjectivity in this study in determining the ISR index. The difference in results for the next researcher is likely to occur because there are no definite benchmarks in determining the items in the ISR indicator.

\section{REFERENCES}

Abul Hassan, S. S. H. 2010. Exploring Corporate Social Responsibility Disclosure: The Case of Islamic Banks. International Journal of Islamic and Middle Eastern Finance and Management 3(3): 203-227. https://doi.org/10.1108/ 1753 8391011072417

Akbar, \& Ghozali, I. 2008. Determinan Pengungkapan Corporate Social Responsibility Bank Syariah (Analisis Data 
Panel pada Bank Syariah). Jurnal Akuntansi.

Al-Sadah, A. K. I. 2007. Corporate Governance of Islamic Banks, Its Characteristics and Effects on Stakeholders and the Role of Islamic Banks Supervisors. University of Surrey. United Kingdom.

Al-Tuwaijri, S. A., Christensen, T. E., \& Hughes, K. E. 2004. The relations among environmental disclosure, environmental performance, and economic performance: A simultaneous equations approach. Accounting, Organizations and Society 29(5-6): 447-471. https://doi. org/10.1016/S0361-3682(03)00032-1

Albrecht, W. S.; Albrecht C. C.; Albrecht, C. O. 2004. Fraud and Corporate Executives: Agency, Stewardship and Broken Trust. Journal of Forensic Accounting.

Andriana, I., Muhamad, R., Meutia, I., \& Natalia, D. 2015. Developing a social media presence strategy for an ECommerce business sharia supervisory board role: A behavioral theory perspective. International Journal of Applied Business and Economic Research, 13(7).

Billzha, R. 2018. Pengaruh Karakteristik Dewan Pengawas Syariah (DPS) Terhadap Profitabilitas Bank Syariah di Indonesia. Finance.

Bindabel, W. A. 2017. The Influence of Shariah (Islamic Principles) Corporate Governance on Cross-Border Merger and Acquisitions Involving Islamic Companies in the Gulf Countries. Retrieved from https:// ww w.dora.dmu.ac.uk/bitstream/handle/ 2086/14468/final Corrected Bindabel .docx $\cdot$ pdf?sequence $=1 \&$ isAllowed $=y$

Birnbaum, P. H. 1984. The Choice of Strategic Alternatives Under Increasing Regulation in High Technology Companies. Academy of Management Journal 27(3): 489-510. https://doi.org/10.2307/256 041

Blair, M. M., \& Stout, L. A. 2001. Director Accountability and the Mediating Role of the Corporate Board. SSRN Electronic Journal. https://doi.org/10.2139/ssrn.266622

Bouten, L., Everaert, P., Van Liedekerke, L., De Moor, L., \& Christiaens, J. 2011. Corporate social responsibility reporting: A comprehensive picture? Accounting Forum. https://doi.org/10.1016/ j.accfor.2011.06.007

Buchanan, A.(1996. Toward a Theory of the Ethics of Bureaucratic Organizations. Business Ethics Quarterly, 6(4), 419-440. https://doi.org/10.2307/3857497

Caldwell, C., Bischoff, S. J., \& Karri, R. 2002. The four umpires: A paradigm for ethical leadership. In Journal of Business Ethics. https://doi.org/10.1023/A:1014 230002724

Caldwell, C., Hayes, L. A., Bernal, P., \& Karri, R. 2008. Ethical stewardship Implications for leadership and trust. In Journal of Business Ethics. https:// doi.org/10.1007/s10551-006-9320-1

Campopiano, G., \& De Massis, A. 2015. Corporate Social Responsibility Reporting: A Content Analysis in Family and Non-family Firms. Journal of Business Ethics. https://doi.org/10.1007/s10551 -014-2174-z

Charles, \& Chariri. 2012. Analisis Pengaruh Islamic Corporate Governance Terhadap Pengungkapan Corporate Social Responsibility (Studi kasus pada Bank Syariah di Asia). Diponegoro Journal of Management: 1-15.

Davis, J. H., Schoorman, F. D., \& Donaldson, L. 1997. Toward A Stewardship Theory Of ManagemenT. Academy of Management Review 22(1): 20-47. https:// doi.org/10.5465/amr.1997.9707180258

Donaldson, L., \& Davis, J. H. 1991. Stewardship Theory or Agency Theory: CEO Governance and Shareholder Returns. Australian Journal of Management 16(1): 49-64. https://doi.org/ $10.1177 / 031289629101600103$

El-Halaby, S., \& Hussainey, K. 2015. The determinants of social accountability disclosure: Evidence from islamic banks around the world. International Journal of Business. 
El-Halaby, S., \& Hussainey, K. 2016. Determinants of compliance with AAOIFI standards by Islamic banks. International Journal of Islamic and Middle Eastern Finance and Management 9(1): 143-168. https://doi.org/10.1108/IME FM-06-2015-0074

Farook, S., Lanis, R., \& Hassan, K. M. 2011. Determinants of Corporate Social Responsibility Disclosure: The Case of Islamic Banks. Research Paper. https:/ / doi.org/10.2139/ssrn.1828624

Fitria, S., \& Hartanti, D. 2010. Islam dan Tanggung Jawab Sosial: Studi Perbandingan Berdasarkan Global Reporting Initiative Indeks dan Islamic Social Reporting Indeks. Simposium Nasional Akuntansi Universitas Jenderal Soedirman .

Friedman, M. 2007. The Social Responsibility of Business Is to Increase Its Profits. In Corporate Ethics and Corporate Governance (173-178). Berlin, Heidelberg: Springer Berlin Heidelberg. https:// doi.org/10.1007/978-3-540-70818-6_14

Gamerschlag, R., Möller, K., \& Verbeeten, F. 2011. Determinants of voluntary CSR disclosure: Empirical evidence from Germany. Review of Managerial Science. https://doi.org/10.1007/s11846-0100052-3

Gao, Y. 2011. CSR in an emerging country: A content analysis of CSR reports of listed companies. Baltic Journal of Management. https://doi.org/10.1108/174652611111 31848

Garas, S. N. 2012. The control of the Shari'a Supervisory Board in the Islamic financial institutions. International Journal of Islamic and Middle Eastern Finance and Management 5(1): 8-24. https://doi.org/10.1108/175383912112 16794

Garriga, E., \& Melé, D. 2013. Corporate Social Responsibility Theories: Mapping the Territory. In Citation Classics from the Journal of Business Ethics (69-96). Dordrecht: Springer Netherlands. https:// doi.org/10.1007/978-94-007-4126-3_4

Gary, S., \& Nowland, J. 2012. Do Directors get "sick" of attending meetings?

Giannarakis, G. 2014. Corporate governance and financial characteristic effects on the extent of corporate social responsibility disclosure. Social Responsibility Journal. https://doi.org/10.1108/SRJ02-2013-0008

Grassa, R. 2013. Shariah supervisory system in Islamic financial institutions. Humanomics 29(4): 333-348. https://doi.org/ 10.1108/H-01-2013-0001

Gray, S., \& Nowland, J. 2013. Do CEOs and Directors Get Sick of Attending Meetings? SSRN Electronic Journal. https://doi.org/10.2139/ssrn.2285344

Sofyani, H., I. Ulum, D. Syam, dan S. Wahyuni. 2012. Islamic social reporting index. Jurnal Dinamika Akuntansi.

Hakiim, N., \& Rafsanjani, H. 2016. Pengaruh Internal Capital Adequency Ratio (CAR), Financing To Deposit Ratio (FDR), dan Biaya Operasional Per Pendapatan Operasional (BOPO) dalam Peningkatan Profitabilitas Industri Bank Syariah di Indonesia. Jurnal Aplikasi Manajemen 14(1): 60-74.

Haniffa, R. 2002. Social Reporting Disclosure-An Islamic Perspective. Indonesian Management and Accounting Research 1(2): 128-146.

Hashim, F., Mahadi, N. D., \& Amran, A. 2015. Corporate Governance and Sustainability Practices in Islamic Financial Institutions: The Role of Country of Origin. Procedia Economics and Finance. https://doi.org/10.1016/ s2212-5671(15)01129-6

Hernandez, M. 2012. Toward an Understanding of the Psychology of Stewardship. Academy of Management Review 37(2): 172-193. https://doi.org/ 10.5465/amr.2010.0363

Humaidi, H., Pituringsih, E., \& M. Irwan, M. I. 2018. Determinan Akuntabilitas Kinerja Sekolah Menengah Negeri SePulau Lombok. EKUITAS (Jurnal Ekonomi Dan Keuangan) 1(4): 532. https:// doi.org/10.24034/j25485024.y2017.v1.i 4.2356 
Husain, S., \& Abdullah, W. 2015. Metafora amanah pengelolaan dana pihak ketiga (dpk) sebagai penopang asset perbankan syariah ditinjau dari aspek trilogi akuntabilitas (studi kasus pada pt. bank bni syariah cabang makassar). Iqtisaduna 1(2): 40-64.

Ilhami, H. 2009. Pertanggungjawaban dewan pengurus syariah sebagai otoritas pengawas kepatuhan syariah bagi bank syariah. Mimbar Hukum 21(3): 409-628.

Indrawaty, \& Wardayati, S. M. 2016. Implementing Islamic Corporate Governance (ICG) and Islamic Social Reporting (ISR) in Islamic Financial Institution (IFI). Procedia-Social and Behavioral Sciences. https://doi.org/10.1016/j.sbspro.2016. 04.042

Julia, T., Rahman, M. P., \& Kassim, S. 2016. Shariah compliance of green banking policy in Bangladesh. Humanomics 32(4): 390-404. https:// doi.org/10. 1108/H-02-2016-0015

Kamla, R., \& Rammal, H. G. 2013. Social reporting by Islamic banks: Does social justice matter? Accounting, Auditing and Accountability Journal. https://doi.org/ 10.1108/AAAJ-03-2013-1268

Keay, A. 2017. Stewardship theory: is board accountability necessary? International Journal of Law and Management 59(6): 1292-1314. https://doi.org/10.1108/ IJLMA-11-2016-0118

Khoiruddin, A. 2013. Corporate Governance dan Pengungkapan Islamic Social Reporting pada Perbankan Syariah di Indonesia. Jurnal Akuntansi Universitas Negeri Semarang.

Lestari, P. 2013. Determinants Of Islamic Social Reporting In Syariah Banks : Case Of Indonesia. International Journal of Business and Management Invention 2(10): 28-34.

Maali, B., Casson, P., \& Napier, C. 2006. Social reporting by islamic banks | ReadCube Articles, 42(2). https://doi. org/10.1111/j.1468-4497.2006.00200.x

Maghfur, M. Z. 2018. Pengaruh Firm Size, Firm Age, Profitability dan Islamic Corporate
Governance Terhadap Islamic Social Reporting Pada Bank Umum Syariah di Indonesia. Skripsi Fakultas Ekonomi dan Bisnis Institut Agama Islam Negeri Surakarta.

Mallin, C., Farag, H., \& Ow-Yong, K. 2014. Corporate social responsibility and financial performance in Islamic banks. Journal of Economic Behavior and Organization. https://doi.org/10.1016/j.jebo. 2014.03.001

Marharani, A. K., \& Yulianto, A. 2016. Faktor-Faktor Yang Mempengaruhi Tingkat Pengungkapan Islamic Social Reporting Pada Bank syariah. Accounting Analysis Journal 5(1).

Masrurroh, D. A., \& Mulazid, A. S. 2017. Analisa Pengaruh Size Perusahaan, Capital Adequacy Ratio (Car), Non Perfoming Financing (Npf), Return On Asset (Roa), Financing Deposit Ratio (Fdr) Terhadap Pengungkapan Corporate Social Responsibility (Csr) Bank Umum Syariah Di Indonesia Periode 2012-201. HUMAN FALAH 4(1).

McWilliams, A., \& Siegel, D. 2000. Corporate social responsibility and financial performance: Correlation or misspecification? Strategic Management Journal. https://doi.org/10.1002/(SICI)10970266(200005)21:5<603::AID-SMJ101> 3.0.CO; $2-3$

Meutia, I., \& Febrianti, D. 2017. Islamic Social Reporting in Islamic Banking: Stakeholders Theory Perspective. SHS Web of Conferences, (January). https://doi.org/ 10.1051/shsconf/20173412001

Mukhibad, H. 2018. Peran Dewan Pengawas Syariah Dalam Pengungkapan. Jurnal Akuntansi Multiparadigma JAMAL 9(2): 299-311.

Murphy, D., \& Ng'ombe, A. 2009. Corporate Social Responsibility. In Corporate Social Responsibility and Urban Development (733). London: Palgrave Macmillan UK. https://doi.org/10.1057/978023023667 7_2

Muth, M., \& Donaldson, L. 1998. Stewardship Theory and Board Structure: a 
contingency approach. Corporate Governance 6(1): 5-28. https://doi.org/10. 1111/1467-8683.00076

Muttakin, M. B., Khan, A., \& Subramaniam, N. 2015. Firm characteristics, board diversity and corporate social responsibility: Evidence from Bangladesh. Pacific Accounting Review. https://doi. org/10.1108/PAR-01-2013-0007

Nathan Garas, S., \& Pierce, C. 2010. Shari'a supervision of Islamic financial institutions. Journal of Financial Regulation and Compliance 18(4): 386-407. https:// doi.org/10.1108/13581981011093695

Nuha, U. 2018. Optimalisasi Peran Dewan Pengawas Syariah Pada Lembaga Keuangan Mikro Syariah (Studi Kasus di Assosiasi Koperasi Warga NU Jepara). Journal of Islamic Banking and Finance 2(2): 211-222.

Nuralam, I. P. 2017. Islamic Marketer Ethics And Its Impact On Customer Satisfaction In The Islamic Banking Institutions: A Case Study Of Bank Muamalat Indonesia. Russian Journal of Agricultural and Socio-Economic Sciences 69(9): 118-125. https://doi.org/10. 18551/rjoas.2017-09.15

Othman, R., \& Thani, A. M. 2010. Islamic Social Reporting Of Listed Companies In Malaysia. International Business $\mathcal{E}$ Economics Research Journal (IBER) 9(4). https://doi.org/10.19030/iber.v9i4.561

Othman, R., Thani, A. M., \& Ghani, E. K. (2009). Determinants Of Islamic Social Reporting Among Top Shariah Approved Companies In Bursa Malaysia. Research Journal of International Studies 12(12): 4-20.

PBI. 2009a. Peraturan Bank Indonesia Nomor 11/3/PBI/2009 Tentang Bank Umum Syariah.

PBI. 2009b. Peraturan Bank Indonesia Nomor 11/33/PBI/2009 Tentang Pelaksanaan Good Corporate Governance bagi Bank Umum Syariah dan Unit Usaha Syariah.

Prastiwi. 2017. Pengaruh Karakteristik Dewan Pengawas Syariah Terhadap Rasio Non-
Performing (NPF) Bank Syariah.

Putra, A. P., Akram, A., \& Hermanto, H. 2018. Determinan Akuntabilitas Kinerja Pemerintah Di Kabupaten Lombok Barat. EKUITAS (Jurnal Ekonomi Dan Keuangan) 2(2): 271-290. https://doi. org/10.24034/j25485024.y2018.v2.i2.39 42

Qolby, M. L. 2013. Faktor - Faktor Yang Mempengaruhi Pembiayaan Pada Perbankan Syariah Di Indonesia Periode Tahun 2007- 2013. Economics Development Analysis Journal 2(4): 367383.

Rahajeng, D. K. 2013. Sharia Governance: Sharia Supervisory Board Model of Islamic Banking and Finance in Indonesia. SSRN Electronic Journal. https://doi.org/10.2139/ssrn.2366722

Rahayu, R. S., \& Cahyati, A. D. 2014. Faktorfaktor yang Mempengaruhi Pengungkapan Corporate Social Responsibility pada Perbankan Syariah. Jrak 5(2): 74-78.

Rama, A. 2015. Analisis Sistem Tata Kelola Syari'ah Bagi Perbankan Syari'ah di Indonesia dan Malaysia. Jurnal Bisnis Islam,8(I): 87-120.

Ramadhani, F. 2016. Pengaruh Ukuran Perusahaan, Profitabilitas, Leverage dan Ukuran Dewan Pengawas Syariah terhadap Pengungkapan Islamic Social Reporting (Studi Empiris Pada Bank Umum Syariah di Indonesia Tahun 2010-2014). JOM Fekon 3(1): 2487-2500.

Rokan, M. K. 2017. Optimalisasi Peran Dewan Pengawas Syariah (DPS) dalam Perbankan Syariah di Medan. EQUILIBRIUM: Jurnal Ekonomi Syariah 5(2): 292-305.

Roring, G. D. J. 2013. Analisis determinan penyaluran kredit oleh bank perkreditan rakyat (BPR) di kota manado. Emba.

Rosiana, R., Arifin, B., \& Hamdani, M. 2015. Pengrauh Ukuran Perusahaan, Profitabilitas,Leverage, Dan Islamic, Governance Score Terhadap Pengungkapan Islamic Social Reporting. Jurnal Bisnis 
Dan Manajemen 5(1): 87-104.

Sadou, A., Alom, F., \& Laluddin, H. 2017). Corporate social responsibility disclosures in Malaysia: Evidence from large companies. Social Responsibility Journal. https://doi.org/10.1108/SRJ-06-20160104

Sulaiman, M., Majid, N. A., \& Arifin, N. M. 2015. Corporate governance of Islamic financial institutions in Malaysia. Asian Journal of Business and Accounting 8(1): 65-93.

Sulistyawati, A. I., \& Yuliani, I. 2017. Pengungkapan Islamic Social Reporting Pada Indeks Saham Syariah Indonesia. Journal of Accounting \& Finance 13(2) 1527.

Tiaraintan Hariyanto, I., \& Suhardianto, N. 2018. Tata Kelola Perusahaan Dan Variabilitas Laba. EKUITAS (Jurnal Ekonomi Dan Keuangan) 2(2): 224-246. https://doi.org/10.24034/j25485024.y2 018.v2.i2.3943
Widayuni, N., \& Hartono, P. 2014. Faktorfaktor yang Mempengaruhi Pengungkapan Corporate Social Responsibility pada Perbankan Syariah di Indonesia dan Malaysia. Fakultas Ekonomi Dan Bisnis Universitas Diponegoro 3(2): 1-11.

Zanariyatim, A., Bayinah, A. N., \& Sahroni, A. 2016. Pengungkapan Corporate Social Responsibility (CSR) Bank Umum Syariah Berdasarkan Islamic Social Reporting Index (Indeks ISR). Jurnal Akuntansi Dan Keuangan Islam 4(1): 85104.

Zoelisty, C., \& Adityawarman. 2014. Amanah Sebagai Konsep Pengendalian Internal Pada Pelaporan Keuangan Masjid (Studi Kasus pada Masjid di Lingkungan Universitas Diponegoro). Diponegoro Journal of Accounting 3(3): 112. 